Удк 633.15:631.5:631.67

DOI https://doi.org/10.32848/agrar.innov.2021.8.14

\title{
МОРФОЛОГІЧНІ ПОКАЗНИКИ ГІБРИДІВ КУКУРУДЗИ РІЗНИХ ГРУП ФАО ЗАЛЕЖНО ВІД ЕЛЕМЕНТІВ ТЕХНОЛОГІЇ ЗА УМОВ ЗРОШЕННЯ
}

\author{
ВОЖЕГОВА Р.А. - доктор сільськогосподарських наук, професор, \\ академік Національної академії аграрних наук України \\ http://orcid.org/0000-0002-3895-5633 \\ Інститут зрошуваного землеробства Національної академії аграрних наук України \\ ЛАВРИНЕНКО Ю.О. - доктор сільськогосподарських наук, професор, \\ академік Національної академії аграрних наук України \\ http://orcid.org/ 0000-0001-9442-8793 \\ Інститут зрошуваного землеробства Національної академії аграрних наук України \\ МАРЧЕНКО Т.Ю. - доктор сільськогосподарських наук, старший науковий співробітник \\ http://orcid.org/0000-0001-6994-3443 \\ Інститут зрошуваного землеробства Національної академії аграрних наук України \\ ПІлЯРСьКА О.О. - кандидат сільськогосподарських наук \\ http://orcid.org/0000-0002-6149-3393 \\ Інститут зрошуваного землеробства Національної академії аграрних наук України \\ ЗАБАРА П.П. - здобувач вищої освіти \\ http://orcid.org/0000-0002-6149-3393 \\ Інститут зрошуваного землеробства Національної академії аграрних наук України \\ САХАЦЬКИЙ Г.І. - кандидат сільськогосподарських наук, доцент \\ https://orcid.org/0000-0002-6763-0846 \\ Державний вищий навчальний заклад \\ «Приазовський державний технічний університет»
}

Постановка проблеми. Стрімкі темпи росту виробництва кукурудзи зумовлені високими кормовими, харчовими й технічними якостями, а також надзвичайно високою позитивною реакцією на новітні технологічні розробки, зокрема на використання краплинного зрошення. Одними з головних елементів технології вирощування різних за групами стиглості гібридів кукурудзи є густота рослин та використання новітніх регулюючих ріст препаратів, які дозволяють найефективніше використовувати агроекологічний потенціал півдня України [1].

Південь України - це особливий регіон, де ефективність будь-якого заходу корегується рівнем вологозабезпеченості; тут можливі непередбачувані реакції різних гібридів кукурудзи, спричинені особливостями клімату, що визначає необхідність корегування технології вирощування у потрібному напрямку [2].

Тому дослідження впливу елементів технології на морфологічні ознаки та врожайність інноваційних гібридів кукурудзи за краплинного способу зволоження $€$ актуальними для виробництва.

Аналіз останніх досліджень і публікацій. Продуктивність вирощування сільськогосподарських культур, зокрема кукурудзи, істотно залежить від дотримання основного елемента технології - щільності посіву. Густота рослин кукурудзи впливає на їх забезпечення основними факторами життя (теплом і вологою), та, відповідно, на ріст і розвиток рослин. Формування оптимальних лінійних розмірів рослин - це не лише придатність до механізованого вирощування і збирання, але й елемент фотосинтетичної системи, від якої залежить кількість органічної речовини, що утворюється під час фотосинтезу [3].

Відомо, що з усіх морфологічних ознак кукурудзи на придатність до механізованого збирання впливають саме ознаки висота рослин та висота прикріплення качанів [4]. Дослідженнями доведено, що висота прикріплення качанів знаходиться в тісній позитивній кореляційній залежності від висоти рослин [5; 6]. Висота рослин і кріплення качанів кукурудзи $є$ невід'ємними ознаками біологічних особливостей гібридів та завжди знаходяться у визначених пропорціях з іншими морфологічними особливостями, притаманними певній групі генотипу гібридів. Вони $є$ одним із визначальних показників реакції рослин на умови вирощування [7; 8]. Ці ознаки впливають на якість збирання, його швидкість та енерговитрати. Чим вище висота рослини, тим більшими будуть витрати на збирання врожаю. Тому для гібридів зернового типу важливо мати невелику висоту рослин (250-275 см) та оптимальне (не менше 50 см) прикріплення господарсько-цінного качана [9].

Висота рослин і висота прикріплення качана залежать від біологічних особливостей рослин та умов їх вирощування. Відсутність вологи у ґрунті та високі температури знижують як висоту рослин, так і висоту прикріплення качанів [10].

Окрім того, висота рослин і висота прикріплення качанів суттєво впливають на стійкість рослин кукурудзи до вилягання. Висота рослин має зворотний зв'язок із ступенем ураження стебловими гнилями (хоча 
і доволі низький), проте встановлено позитивний зв'язок вилягання рослин і висоти прикріплення качана, що необхідно враховувати під час розроблення оптимальної моделі гібриду. Вочевидь, переміщення центру ваги рослин вище поверхні ґрунту в генотипів із високим розташуванням качанів призводить до зменшення механіки зламу стебла унаслідок хвороб та пошкоджень, тому висота кріплення качана повинна мати певні обмеження. Проте оптимальні параметри розташування качана необхідно визначати в окремих груп генотипів, насамперед у груп із різною тривалістю вегетаційного періоду. Висота рослин і висота прикріплення качана залежить від біологічних особливостей рослин та умов їх вирощування [11].

Одним 3 ефрективних шляхів підвищення врожайності $€$ застосування різноманітних регулюючих ріст препаратів із адаптогенною дією, котрі в більшості випадків характеризуються невисокою ринковою ціною та негативно не впливають на довкілля. Рослинницьке сьогодення світового рівня спрямовує зусилля на максимально можливе зростання групи біопрепаратів, які разом із позитивним впливом на рослини розглядаються як елемент біологізації технологій і як напрям зростання об'ємів виробництва органічної продукції [12].

Дослідження зміни морфологічних показників і врожайності гібридів кукурудзи за різної щільності посіву та обробки біопрепаратами $€$ необхідними та актуальними. Особливої уваги потребує вивчення взаємозв'язку морфологічних показників з урожайністю зерна інноваційних гібридів кукурудзи за умов нового способу поливу - краплинного зрошення.

Мета дослідження - встановлення морфологічних показників і врожайності зерна інноваційних вітчизняних гібридів кукурудзи різних груп ФАО за різної густоти рослин та обробки біопрепаратами на краплинному зрошенні в умовах Південного Степу України, а також установлення індексу співвідношення висоти прикріплення качана до висоти рослин гібридів кукурудзи залежно від їх густоти та дії біологічних препаратів.

Матеріали та методика досліджень. Дослідження тривали упродовж 2018-2020 рр. на дослідному полі Інституту зрошуваного землеробства НАAН, розташованому в зоні Інгулецького зрошуваного масиву. Грунт дослідної ділянки - темно-каштановий середній суглинковий слабкосолонцюватий із глибоким рівнем залягання ґрунтових вод.

Трифракторний дослід закладали методом розщеплених рендомізованих блоків. Дослідження проводили в чотириразовій повторності. Посівна площа ділянок становила 50,0 м², облікова - 30,0 м².

Фактор А - різні за групами стиглості гібриди: Степовий (ФАО 190), Каховський (ФАО З80), Чонгар (ФАО 420), Арабат (ФАО 430).

Гібрид Степовий (ФАО 190). Гібрид ранньостиглий, дозріває на зерно в зоні Південного Степу за 90-97 діб. Гібрид стійкий до вилягання й ураження головними хворобами і шкідниками. Характеризується інтенсивною вологовіддачею зерна, добре реагує на покращання умов вирощування. Придатний для вирощування за енергозберігаючими технологіями та в умовах природ- ного зволоження. Може використовуватися в якості попередника під озимі культури. Насінництво ведеться на стерильній основі С-типу. Гібрид занесений до Державного реєстру сортів рослин, придатних для поширення в Україні з 2019 р.

Гібрид Каховський (ФАО 380). Середньостиглий, дозріває на зерно в зоні Південного Степу за 115-120 діб. Гібрид має добру стійкість до кореневого і стеблового вилягання, відрізняється доброю стійкістю до посухи та жари. Насінництво ведеться на стерильній основі М-типу. Гібрид занесений до Державного реєстру сортів рослин, придатних для поширення в Україні з $2014 \mathrm{p}$.

Гібрид Чонгар (ФАО 420). Середньопізній, дозріває на зерно в зоні Південного Степу за 120-124 діб. Інтенсивного типу. Висока стійкість до вилягання (9 балів) зумовлює можливість пізнього збирання без значних втрат врожаю. Вирізняється досить високою посухостійкістю і жаростійкістю. Насінництво ведеться на стерильній основі М-типу. Гібрид занесений до Державного реєстру сортів рослин, придатних для поширення в Україні з 2015 р.

Гібрид Арабат (ФАО 430). Середньопізній, дозріває на зерно в зоні Південного Степу за 120-125 діб. Інтенсивного типу. Гібрид стійкий до вилягання. Відрізняється швидкою втратою вологи під час дозрівання. Стійкість до ураження головними хворобами висока. Стійкий до пошкодження шкідниками. Насінництво ведеться на стерильній основі М-типу. Гібрид занесений до Державного реєстру сортів рослин, придатних для поширення в Україні з 2015p.

Фактор В - густота рослин гібридів $(70,80,90$ тис. рослин/га). Фактор С - обробка гібридів кукурудзи біологічними препаратами Біо-гель і Хелафіт комбі, занесених до Реєстру дозволених для використання пестицидів.

Агротехніка вирощування і методика досліджень загальноприйнята для умов зрошення, крім фракторів, що вивчалися. Застосовували краплинне зрошення з рівнем передполивної вологості ґрунту $80 \%$ HВ у шарі ґрунту 0-50 см. Методика досліджень є загальновизнаною для умов зрошення [13; 14].

Результати дослідження. За результатами проведеного дослідження встановлено суттєву залежність лінійних розмірів рослин із генетичними особливостями гібриду, густотою рослин, обробкою біопрепаратами (табл. 1).

За узагальненими даними дослідження встановлено, що на висоту рослин істотно впливає тривалість вегетаційного періоду гібридів. Зокрема, в ранньостиглого гібриду кукурудзи Степовий висота рослин у середньому за три роки становила 229,2 см, у середньостиглого гібриду Каховський - 267,7 см, а у групі середньопізніх гібридів Чонгар та Арабат - 280,2 та 279,3 см відповідно. Така тенденція показує, що подовження тривалості вегетаційного періоду збільшує висоту рослин у гібридів кукурудзи.

Висота рослин істотно залежала від обробки біопрепаратами гібридів кукурудзи. Максимальне значення висоти рослин було отримано за обробки біопрепара- 
Висота рослин гібридів кукурудзи залежно від густоти рослин і дії біологічних препаратів, см

Таблиця 1 (середнє за 2018-2020 рр.)

\begin{tabular}{|c|c|c|c|c|c|c|}
\hline \multirow{2}{*}{$\begin{array}{c}\text { Гібрид } \\
\text { (фактор А) }\end{array}$} & \multirow{2}{*}{$\begin{array}{c}\text { Густота рослин, } \\
\text { тис. р./га } \\
\text { (фрактор В) }\end{array}$} & \multicolumn{3}{|c|}{$\begin{array}{l}\text { Обробіток препаратами } \\
\text { (фактор С) }\end{array}$} & \multicolumn{2}{|c|}{$\begin{array}{c}\text { У середньому } \\
\text { за фактором }\end{array}$} \\
\hline & & $\begin{array}{c}\text { Контроль, } \\
\text { без обробітку }\end{array}$ & Біо-гель & Хелафіт комбі & A & B \\
\hline \multirow{3}{*}{$\begin{array}{l}\text { Степовий } \\
\text { (ФАО 190) }\end{array}$} & 70 & 223,9 & 224,2 & 225,6 & \multirow{3}{*}{229,2} & 224,6 \\
\hline & 80 & 228,9 & 230,7 & 232,8 & & 230,8 \\
\hline & 90 & 230,8 & 232,5 & 233,7 & & 232,3 \\
\hline Середнє & & 227,9 & 229,1 & 230,7 & & \\
\hline \multirow{3}{*}{$\begin{array}{c}\text { Каховський } \\
(\text { ФАО 380) }\end{array}$} & 70 & 263,5 & 265,4 & 266,8 & \multirow{3}{*}{267,7} & 265,2 \\
\hline & 80 & 264,8 & 266,4 & 267,7 & & 266,3 \\
\hline & 90 & 270,7 & 271,2 & 272,9 & & 271,6 \\
\hline Середнє & & 266,3 & 267,7 & 269,1 & & \\
\hline \multirow{3}{*}{$\begin{array}{c}\text { Чонгар } \\
\text { (ФАО 420) }\end{array}$} & 70 & 272,2 & 275,8 & 276,7 & \multirow{3}{*}{280,2} & 274,9 \\
\hline & 80 & 277,7 & 278,5 & 280,7 & & 279,0 \\
\hline & 90 & 284,8 & 286,5 & 286,4 & & 285,6 \\
\hline Середнє & & 278,2 & 280,3 & 281,9 & & \\
\hline \multirow{3}{*}{$\begin{array}{c}\text { Арабат } \\
\text { (ФАО 430) }\end{array}$} & 70 & 270,5 & 271,1 & 272,3 & \multirow{3}{*}{279,3} & 271,3 \\
\hline & 80 & 279,3 & 280,4 & 281,6 & & 280,4 \\
\hline & 90 & 284,9 & 286,3 & 287,8 & & 286,3 \\
\hline Середнє & & 278,3 & 279,3 & 280,6 & & \\
\hline Середнє за фактором C & & 262,7 & 264,1 & 265,6 & & \\
\hline \multicolumn{7}{|c|}{ Оцінка істотності часткових відмінностей } \\
\hline \multicolumn{2}{|c|}{$\mathrm{HIP}_{05}, \mathrm{CM}$} & \multicolumn{5}{|c|}{$A=6,52-6,73 ; B=2,12-2,59 ; C=1,12-1,19$} \\
\hline
\end{tabular}

тами. Зокрема, в середньому за три роки висота рослин за обробки Хелафіт комбі становила 265,6 см, а за обробки Біо-гель - 264,1 см, приріст висоти відносно контрольного варіанту становив 2,9 см і 1,4 см відповідно.

Щодо висоти рослин за різної густоти слід відзначити, що загущеність посівів призводить до збільшення лінійної висоти рослини (максимальна висота спостерігалася за густоти 90 тис. рослин/га). Максимальна висота рослини $(287,8$ см) спостерігалась у гібриду Арабат за щільності посіву 90 тис. рослин/га та обробки препаратом Хелафіт комбі.

Аналізуючи попередні дослідження ліній (батьківських компонентів гібридів, що досліджувалися), можна порівняти за висотою рослин лінії і створені на їхній основі гібриди [15]. У лінії батьківських компонентів висота рослин залежала від їх генотипу, а не від тривалості періоду вегетації. У створених за допомогою цих ліній гібридів висота рослин збільшувалася зі збільшенням вегетаційного періоду. Обробка біопрепаратами сприяла збільшенню висоти рослин як батьківських компонентів, так і створених гібридів. Загущеність посівів призводить до збільшення лінійної висоти рослин як батьківських компонентів, так і гібридів.

У наших дослідах спостерігалася чітка закономірність збільшення висоти прикріплення верхнього (продуктивного) качана на рослині за підвищення густоти посіву від 70 до 90 тис. рослин/га (табл. 2).

У середньому за роки дослідження в рослин гібриду Степовий (ФАО 190) приріст висоти прикріплення качанів становив $3,4 \%$, що свідчить про більш сильну реакцію на загущення ранньостиглого гібрида. Середньостиглий гібрид Каховський і середньопізній гібрид Чонгар за умови загущення рослин від 70 до 90 тис. рослин/га показали приріст висоти прикріплення качана на рівні 1,6-1,8\%, що вказує на незначну реакцію цих гібридів на загущеність посівів.

Серед досліджуваних гібридів найбільша висота прикріплення качана відмічена в середньопізнього гібриду Арабат (у середньому 122,9 см), мінімальна висота спостерігалась у гібриду Степовий - 97,1 см.

У середньому за дослідом обробка біопрепаратами впливала на висоту прикріплення верхнього (продуктивного) качана: на контрольному варіанті цей показник становив 111,4 см, причому Біо-гель збільшив висоту прикріплення качана на 0,8 см (або на 0,7\%), а Хелафіт комбі - на 1,5 см (або на 1,3\%).

Висота прикріплення качанів змінювалась як у рослин батьківських компонентів, так і у створених на їх основі гібридів - у загущених посівах качани формувалися на стеблах рослин вище, ніж у розріджених варіантах. Обробіток біопрепаратами сприяв збільшенню висоти прикріплення верхнього качана як у батьківських компонентів, так і у створених гібридів. Але на відміну від батьківських компонентів, у котрих висота прикріплення качана не залежить від групи ФАО, у створених на їхній основі гібридів висота прикріплення качана залежала від тривалості вегетаційного періоду.

За експертної оцінки рослин кукурудзи відповідно до Методики проведення ділянкового (POST-control) і лабораторного сортового контролю, що передбачає морфологічну кількісну ознаку «рослина: співвідношення висоти прикріплення качана до висоти рослини», нами визначено середнє значення цієї індексної ознаки. 
Висота прикріплення верхнього (продуктивного) качана гібридів кукурудзи залежно від густоти рослин і дії біологічних препаратів, см (середнє за 2018-2020 рр.)

\begin{tabular}{|c|c|c|c|c|c|c|}
\hline \multirow{2}{*}{$\begin{array}{c}\text { Гібрид } \\
\text { (фактор A) }\end{array}$} & \multirow{2}{*}{$\begin{array}{c}\text { Густота рослин, } \\
\text { тис. p./га } \\
\text { (фактор В) }\end{array}$} & \multicolumn{3}{|c|}{$\begin{array}{l}\text { Обробіток препаратами } \\
\text { (фактор C) }\end{array}$} & \multicolumn{2}{|c|}{$\begin{array}{c}\text { У середньому } \\
\text { за фактором }\end{array}$} \\
\hline & & $\begin{array}{c}\text { Контроль, } \\
\text { без обробітку }\end{array}$ & Біо-гель & Хелафіт комбі & A & B \\
\hline \multirow{3}{*}{$\begin{array}{l}\text { Степовий } \\
\text { (ФАО 190) }\end{array}$} & 70 & 95,1 & 96,1 & 96,5 & \multirow{3}{*}{97,1} & 95,9 \\
\hline & 80 & 95,8 & 96,3 & 96,7 & & 96,3 \\
\hline & 90 & 98,1 & 99,7 & 99,9 & & 99,2 \\
\hline Середнє & & 96,3 & 97,4 & 97,7 & & \\
\hline \multirow{3}{*}{$\begin{array}{l}\text { Каховський } \\
\text { (ФАО 380) }\end{array}$} & 70 & 106,4 & 107,3 & 107,9 & \multirow{3}{*}{108,1} & 107,2 \\
\hline & 80 & 107,6 & 108,3 & 108,5 & & 108,1 \\
\hline & 90 & 108,7 & 108,9 & 109,5 & & 109,0 \\
\hline Середнє & & 107,6 & 108,2 & 108,6 & & \\
\hline \multirow{3}{*}{$\begin{array}{c}\text { Чонгар } \\
\text { (ФАО 420) }\end{array}$} & 70 & 118,7 & 119,1 & 119,8 & \multirow{3}{*}{120,4} & 119,2 \\
\hline & 80 & 119,9 & 120,5 & 121,6 & & 120,7 \\
\hline & 90 & 120,5 & 121,3 & 122,4 & & 121,4 \\
\hline Середнє & & 119,7 & 120,3 & 121,3 & & \\
\hline \multirow{3}{*}{$\begin{array}{c}\text { Арабат } \\
\text { (ФАО 430) }\end{array}$} & 70 & 119,9 & 120,2 & 121,5 & \multirow{3}{*}{122,9} & 120,5 \\
\hline & 80 & 122,6 & 123,7 & 124,6 & & 123,6 \\
\hline & 90 & 123,5 & 124,6 & 125,4 & & 124,5 \\
\hline Середнє & & 122,0 & 122,8 & 123,8 & & \\
\hline Середнє за фрактором C & & 111,4 & 112,2 & 112,9 & & \\
\hline \multicolumn{7}{|c|}{ Оцінка істотності часткових відмінностей } \\
\hline \multicolumn{2}{|c|}{$\mathrm{HIP}_{05}, \mathrm{CM}$} & \multicolumn{5}{|c|}{$\mathrm{A}=4,52-4,73 ; \mathrm{B}=1,06-1,19 ; \mathrm{C}=0,17-0,25$} \\
\hline
\end{tabular}

Нині прийнята така градація кодів прояву ознаки «рослина: співвідношення висоти прикріплення качана до висоти рослини»: код 1 - дуже мале з індексом < 0,50; 3 - мале - 0,51-0,55; 5 - середнє 0,56-0,60; 7 - велике 0,61-0,70; 9 - дуже велике з індексом > 0,71 [16, 17].

Нами проведено ідентифікацію гібридів за ознакою: «рослина: співвідношення прикріплення качана до висоти рослини». Показник досліджуваних гібридів коливався від 0,402 до 0,446 (табл. 3).

Аналіз індексу співвідношення висоти прикріплення качана до висоти рослин за групами стиглості ФАО в середньому за роки дослідження показав типове зростання оцінок у пізньостиглих гібридів Чонгар та Арабат (0,429 та 0,440 відповідно).

3 метою пошуку зв'язку між морфологічними параметрами рослин гібридів кукурудзи визначено коефіцієнти кореляції між висотою рослин і висотою прикріплення качана та індексом їх співвідношення.

За літературними джерелами [18-20] висота рослин та висота прикріплення качана в гібридів позитивно корелюють, але не стабільно за роками, з коливанням у межах 0,270-0,880. У дослідженнях В. Ю. Черчеля, В. А. Марочка, М. М. Таганцової з високим рівнем достовірності виявлено кореляційний зв'язок між цими показниками $(r=0,602)$. Умови вирощування не призводять до суттєвих змін взаємозв'язків [21].

Визначення зв'язку між біометричними параметрами рослини та індексом співвідношення висоти прикріплення качана до висоти рослини показало, що формування цього показника залежить від висоти прикріплення качана (коефіцієнт кореляції між ними становив $r=0,513)$. Висота рослин із індексом співвідношення забезпечила нестабільний рівень залежності, що характеризувався низьким коефіцієнтом кореляції $(r=0,199)$.

Коефіцієнт кореляції між висотою рослин і висотою прикріплення качана досить високий і стабільний, що $€$ досить закономірним явищем $(r=0,937)$. Між індексом співвідношення висоти прикріплення качана до висоти рослини та врожайністю зерна гібридів кукурудзи існує також досить високий зв'язок ( $r=0,687)$. Тому індекс співвідношення висоти прикріплення качана до висоти рослини можна використовувати не тільки під час проведення експертизи гібридів кукурудзи на відмінність, однорідність і стабільність, але й як індикативну ознаку в разі проведення добору за високою врожайністю зерна.

Діапазон варіювання «індексу співвідношення» в гібридів кукурудзи за роками вивчення становив від 0,401 (гібрид Каховський із густотою 90 тис. рослин/га та обробкою Хелафріт комбі) до 0,436 (гібрид Арабат за густотою 90 тис. рослин/га та обробкою Хелафріт комбі). Найбільші коливання цього показника за роками дослідження відмічено в гібриду Степовий (ФАО 190) з діапазоном 0,014, мінімальними коливаннями відзначився гібрид Каховський із діапазоном 0,006.

Слід зазначити, що всі гібриди мали досить сталий прояв ознаки, тобто співвідношення висоти прикріплення качана до висоти рослини $є$ генетично зумовленою ознакою, котра добре ідентифікує зразки кукурудзи та може використовуватися для складання опису й характеристики нового матеріалу.

Проведені спостереження показали, що врожайність зерна залежить від генотипу гібриду, густоти рослин та обробки препаратами. Найвищу врожайність зерна 
Індекс співвідношення висоти прикріплення качана до висоти рослини гібридів кукурудзи залежно від густоти рослин та дії біологічних препаратів (середнє за 2018-2020 рр.)

\begin{tabular}{|c|c|c|c|c|c|c|}
\hline \multirow{2}{*}{$\begin{array}{c}\text { Гібрид } \\
\text { (фактор А) }\end{array}$} & \multirow{2}{*}{$\begin{array}{c}\text { Густота } \\
\text { рослин, } \\
\text { тис. р./га } \\
\text { (фактор В) }\end{array}$} & \multicolumn{3}{|c|}{$\begin{array}{l}\text { Обробіток препаратами } \\
\text { (фактор С) }\end{array}$} & \multicolumn{2}{|c|}{$\begin{array}{c}\text { У середньому } \\
\text { за фактором }\end{array}$} \\
\hline & & $\begin{array}{c}\text { Контроль, } \\
\text { без обробітку }\end{array}$ & Біо-гель & Хелафіт комбі & A & B \\
\hline \multirow{3}{*}{$\begin{array}{l}\text { Степовий } \\
\text { (ФАО 190) }\end{array}$} & 70 & 0,425 & 0,429 & 0,428 & \multirow{3}{*}{0,423} & 0,427 \\
\hline & 80 & 0,419 & 0,417 & 0,415 & & 0,417 \\
\hline & 90 & 0,425 & 0,429 & 0,427 & & 0,427 \\
\hline Середнє & & 0,423 & 0,425 & 0,423 & & \\
\hline \multirow{3}{*}{$\begin{array}{c}\text { Каховський } \\
\text { (ФАО 380) }\end{array}$} & 70 & 0,404 & 0,404 & 0,404 & \multirow{3}{*}{0,403} & 0,404 \\
\hline & 80 & 0,406 & 0,407 & 0,405 & & 0,406 \\
\hline & 90 & 0,402 & 0,402 & 0,401 & & 0,401 \\
\hline Середнє & & 0,404 & 0,404 & 0,403 & & \\
\hline \multirow{3}{*}{$\begin{array}{c}\text { Чонгар } \\
\text { (ФАО 420) }\end{array}$} & 70 & 0,436 & 0,432 & 0,433 & \multirow{3}{*}{0,429} & 0,433 \\
\hline & 80 & 0,432 & 0,433 & 0,433 & & 0,432 \\
\hline & 90 & 0,423 & 0,423 & 0,424 & & 0,423 \\
\hline Середнє & & 0,430 & 0,429 & 0,430 & & \\
\hline \multirow{3}{*}{$\begin{array}{c}\text { Арабат } \\
\text { (ФАО 430) }\end{array}$} & 70 & 0,443 & 0,443 & 0,446 & \multirow{3}{*}{0,440} & 0,444 \\
\hline & 80 & 0,439 & 0,441 & 0,442 & & 0,440 \\
\hline & 90 & 0,433 & 0,435 & 0,436 & & 0,434 \\
\hline Середнє & & 0,438 & 0,440 & 0,441 & & \\
\hline Середнє за фрактором C & & 0,424 & 0,425 & 0,424 & & \\
\hline \multicolumn{7}{|c|}{ Оцінка істотності часткових відмінностей } \\
\hline \multicolumn{2}{|l|}{$\mathrm{HIP}_{05}$} & \multicolumn{5}{|c|}{$0,0023-0,002$} \\
\hline
\end{tabular}

відмічено в середньопізнього гібриду Арабат - 17,65 т/га (табл. 4).

Найбільша врожайність зерна в середньому за дослідом спостерігалась у середньопізніх гібридів Чонгар та Арабат і знаходилася на рівні 16,48-16,53 т/га. На приріст урожайності зерна (порівняно з необробленим контролем) істотно вплинули біопрепарати: приріст урожайності зерна в гібридів Чонгар та Арабат був на рівні 0,25-0,44 т/га і 0,42-0,73 т/га відповідно.

Найефективнішим серед препаратів виявився Хелафріт комбі. Зокрема, за його використання ранньостиглий гібрид Степовий показав найвищу врожайність зерна - 11,53 т/га, приріст урожайності становив 1,04 т/га (або 9,9\%). Середньостиглий гібрид Каховський показав урожайність за використання препарату Хелафріт комбі 12,77 т/га, приріст врожайності - 1,14 т/га (або 9,8\%). Середньостиглий гібрид Чонгар показав урожайність за використання препарату Хелафріт комбі 16,71 т/га, приріст врожайності становив 0,44 т/га (або 2,63\%). Середньостиглий гібрид Арабат показав урожайність за використання препарату Хелафіт комбі 16,91 т/га, приріст урожайності - 0,73 т/га (або 4,31\%).

Густота рослин впливала на урожайність зерна гібридів. Для гібридів різних груп стиглості встановлена оптимальна густота рослин задля отримання максимального врожаю.

Ранньостиглий гібрид Степовий максимальну врожайність показав за густоти 90 тис. рослин/га - 11,36 т/га. Розрідження посіву до 80 тис. рослин/га призвело до падіння врожаю на 2,72\%, зменшення густоти до 70 тис. рослин/га - до зменшення врожаю зерна на 5,02 \%.
Середньостиглий гібрид Каховський максимальну врожайність 12,47 т/га показав за густоти 80 тис. рослин/га, причому зменшення густоти до 70 тис. рослин/га призвело до падіння врожайності на $3,52 \%$, а збільшення густоти до 90 тис. рослин/га зменшило урожайність на $1,04 \%$.

Середньопізні гібриди Чонгар та Арабат максимальну врожайність показали за густоти 70 тис. рослин/ га - 17,20 та 17,31 т/га відповідно. За збільшення густоти до 80 тис. рослин/га врожайність зерна цих гібридів мала тенденцію до зниження на 1,33-3,18\%, а збільшення густоти до 90 тис. рослин/га призвело до різкого падіння врожайності на 10,34-11,27\% порівняно з густотою 70 тис. рослин/га.

У досліді максимальну урожайність показав гібрид Арабат (ФАО 420) за густоти 70 тис. рослин/га та обробки препаратом Хелафіт комбі - 17,65 т/га.

Аналізуючи результати наших попередніх досліджень із врожайності батьківських компонентів ДК 445 (батьківський компонент гібридів Арабат, Віра, Гілея); ДК 411 (батьківський компонент гібридів Чонгар, Ламасан); ДК 281 (батьківський компонент гібриду Степовий); ДК 247 (батьківський компонент гібриду Скадовський) [15], можна зробити такий висновок: батьківські компоненти і створені на їхній основі гібриди однаково реагують на щільність посіву. Середньопізні лінії та гібриди мають максимальну врожайність за густоти 70 тис. рослин/га та різко знижують урожайність у разі загущення посівів. Середньостиглі батьківські компоненти та гібриди максимум врожайності мають за густоти 80 тис. рослин/га. Ранньостиглі лінії (батьківські компоненти) і створені на їхній основі гібриди 
Урожайність зерна гібридів кукурудзи залежно від густоти рослин і дії біологічних препаратів, т/га (середнє за 2018-2020 рр.)

\begin{tabular}{|c|c|c|c|c|c|c|}
\hline \multirow{2}{*}{$\begin{array}{c}\text { Гібрид } \\
\text { (фактор А) }\end{array}$} & \multirow{2}{*}{$\begin{array}{c}\text { Густота рослин } \\
\text { тис. р./га } \\
\text { (фактор В) }\end{array}$} & \multicolumn{3}{|c|}{$\begin{array}{l}\text { Обробіток препаратами } \\
\text { (фактор C) }\end{array}$} & \multicolumn{2}{|c|}{$\begin{array}{c}\text { У середньому } \\
\text { за фактором }\end{array}$} \\
\hline & & $\begin{array}{c}\text { Контроль, } \\
\text { без обробітку }\end{array}$ & Біо-гель & Хелафіт комбі & A & B \\
\hline \multirow{3}{*}{$\begin{array}{l}\text { Степовий } \\
\text { (ФАО 190) }\end{array}$} & 70 & 10,41 & 10,95 & 11,16 & \multirow{3}{*}{11,06} & 10,79 \\
\hline & 80 & 10,54 & 11,35 & 11,78 & & 11,05 \\
\hline & 90 & 10,69 & 11,57 & 11,87 & & 11,36 \\
\hline Середнє & & 10,49 & 11,19 & 11,53 & & \\
\hline \multirow{3}{*}{$\begin{array}{c}\text { Каховський } \\
\text { (ФАО 380) }\end{array}$} & 70 & 11,26 & 12,35 & 12,48 & \multirow{3}{*}{12,28} & 12,03 \\
\hline & 80 & 11,96 & 12,55 & 12,89 & & 12,47 \\
\hline & 90 & 11,68 & 12,41 & 12,94 & & 12,34 \\
\hline Середнє & & 11,63 & 12,44 & 12,77 & & \\
\hline \multirow{3}{*}{$\begin{array}{c}\text { Чонгар } \\
\text { (ФАО 420) }\end{array}$} & 70 & 16,84 & 16,94 & 17,57 & \multirow{3}{*}{16,48} & 17,20 \\
\hline & 80 & 16,81 & 17,18 & 17,36 & & 16,97 \\
\hline & 90 & 15,15 & 15,84 & 16,15 & & 15,26 \\
\hline Середнє & & 16,27 & 16,46 & 16,71 & & \\
\hline \multirow{3}{*}{$\begin{array}{c}\text { Арабат } \\
\text { (ФАО 430) }\end{array}$} & 70 & 17,08 & 17,16 & 17,65 & \multirow{3}{*}{16,53} & 17,31 \\
\hline & 80 & 16,31 & 16,76 & 17,21 & & 16,76 \\
\hline & 90 & 15,15 & 15,54 & 15,88 & & 15,52 \\
\hline Середнє & & 16,18 & 16,49 & 16,91 & & \\
\hline \multicolumn{2}{|c|}{ У середньому за фрактором C } & 13,64 & 14,15 & 14,48 & & \\
\hline \multicolumn{7}{|c|}{ Оцінка істотності часткових відмінностей } \\
\hline \multicolumn{2}{|c|}{$\mathrm{HIP}_{05}, \mathrm{~T} /$ га } & \multicolumn{5}{|c|}{$A=2,18-2,25 ; B=1,17-1,19 ; C=0,23-0,32$} \\
\hline
\end{tabular}

мають максимальну врожайність за густоти 90 тис. рослин/га.

Висновки. Ростові процеси рослин кукурудзи досить важливі з погляду на формування надземної маси й максимальну продуктивність. Архітектоніка рослин кукурудзи $є$ індикативною ознакою потенційної продуктивності гібридів, а також інформативною базою для визначення дії окремих елементів технології.

Встановлено, що на висоту рослин істотно впливає тривалість їх вегетаційного періоду. Зокрема, в ранньостиглого гібриду кукурудзи Степовий висота рослин у середньому за три роки становила 229,2 см, у середньостиглого гібриду Каховський - 267,7 см, а у групі середньопізніх гібридів Чонгар і Арабат - 280,2 та 279,3 см відповідно. Ця тенденція показує, що подовження тривалості вегетаційного періоду збільшує висоту рослин у гібридів кукурудзи.

Встановлено, що висота рослин гібридів кукурудзи істотно залежала від обробки біопрепаратами. Максимальне значення висоти рослин було отримано за обробки біопрепаратами, зокрема в середньому за три роки висота рослин за обробки Хелафіт комбі становила 265,6 см, за обробки Біо-гелем - 264,1 см; приріст висоти до контрольного варіанту становив 2,9 см і 1,4 см відповідно. Встановлено, що загущеність посівів призводить до збільшення лінійної висоти рослини: максимальна висота рослин гібридів кукурудзи спостерігалася за густоти 90 тис. рослин/га.

Установлено, що оброблення біопрепаратами впливало на висоту прикріплення верхнього (продуктивного) качана: на контрольному варіанті $(111,4$ см) Біо-гель збільшив висоту прикріплення качана на 0,8 см (або на 0,7\%), а Хелафіт комбі - на 1,5 см (або на 1,3\%).
Співвідношення висоти прикріплення качана до висоти рослини $\epsilon$ генетично зумовленою ознакою, яка добре ідентифікує зразки кукурудзи та може використовуватися для складання опису й характеристики нового матеріалу.

Встановлено, що середньопізні гібриди негативно реагують на загущеність посівів. Середньопізні гібриди формують максимальну урожайність за густоти 70 тис. рослин/га $(17,20-17,31$ т/га) і різко знижують врожайність у разі загущеності посівів (до 15,26-15,52 т/га). Середньостиглі гібриди максимум врожайності формують за густоти 80 тис. рослин/га (12,47 т/га). Ранньостиглі гібриди максимальну врожайність продукують за густоти 90 тис. рослин/га (11,36 т/га).

Найефективнішим серед біопрепаратів виявився Хелафіт комбі: за його використання ранньостиглий гібрид Степовий показав найвищу врожайність зерна 11,53 т/га, приріст урожайності до контролю становив 1,04 т/га (або 9,9\%); середньостиглий гібрид Каховський показав урожайність на рівні 12,77 т/га, приріст урожайності - 1,14 т/га (або 9,8\%); урожайність середньостиглого гібрида Чонгар становила 16,71 т/га, приріст урожайності - 0,44 т/га (або 2,63\%); урожайність середньостиглого гібриду Арабат становила 16,91 т/га, приріст урожайності - 0,73 т/га (або 4,31\%).

\section{СПИСОК ВИКОРИСТАНОЇ ЛІТЕРАТУРИ:}

1. Гадзало Я. М., Вожегова Р. А., Коковіхін С. В., Біляєва І. М., Дробітько А. В. Наукове обґрунтування технологій вирощування кукурудзи на зрошуваних землях із урахуванням гідротермічних чинників i змін клімату. Зрошуване землеробство: збірник 
наукових праць. 2020. № 73. C. 21-26. https://doi. org/10.32848/0135-2369.2020.73.3

2. Коковіхін С. В., Писаренко П. В., Біднина І. О., Шарій В. О., Бойценюк Х. І. Науково-практичні аспекти планування та оперативного управління режимами зрошення сільськогосподарських культур із використанням інформаційних технологій. Зрошуване землеробство: збірник наукових праць. 2020. № 73. C. 43-49. https://doi.org/10.32848/01352369.2020.73.8.

3. Орлянский Н. А., Зубко Д. Г. Селекция кукурузы на адаптивность и загущение посевов. Кукуруза и сорго. 2005. № 5. C. 2-4.

4. Зозуля О. Л., Паламарчук В. Д., Мазур В. А. Кукурудза: створення та вирощування гібридів. Вінниця: ФОП Данилюк, 2009. 199 с.

5. Паламарчук В. Д., Паламарчук О. Д., Колісник О. М. Селекція та створення гібридів кукурудзи, придатних до механізованого вирощування та виробництва альтернативних джерел енергії. Хранение и переработка зерна. Научно-практический журнал. № 2(128). 2010. С. 23-25.

6. Паламарчук В. Д., Поліщук І. С., Каленська С. М., Єрмакова Л. М. Біологія та екологія сільськогосподарських рослин. Вінниця, 2013. 636 с.

7. Каменщук Б. Д. Агроекологічний вплив умов вирощування на зернову продуктивність гібридів кукурудзи різних груп стиглості. Стан та перспективи розвитку рослинницької галузі в умовах змін клімату: 4-а Міжнар. наук.-практ. конф. молодих вчених, 1-3 липня 2009 р.: тези доповідей. Харків, IP ім. В.Я. Юр'єва УААН, 2009. С. 125-126.

8. Сіроха О. Л. Вплив удобрення на біометричні показники та показники вирівняності рослин кукурудзи різної групи стиглості. Збірник наукових праць Вінницького національного аграрного університету. Серія: Сільськогосподарські науки. Вінниця. 2014. Вип. 5(82). С. 37-47.

9. Marchenko T. Yu. Innovative elements of cultivation technology of corn hybrids of different FAO groups in the conditions of irrigation. Natural sciences and modern technological solutions: knowledge integration in the XXI century: collective monograph Lviv-Torun: Liha-Pres, 2019. P. 137-153. doi.org/ 10.36059/978-966-397-154-4/135-152.

10. Сікалова О. В., Івлева Т. В., Деркач І. Б., Чернобай Л. М. Новий вихідний матеріал кукурудзи з комплексом цінних селекційних ознак та властивостей. Генетичні ресурси рослин. 2011. № 9. С. 131-137.

11. Лавриненко Ю. О., Плоткін С. Я. та ін. Адаптивна характеристика нових гібридів кукурудзи. Таврійський науковий вісник: збірник наукових праць ХДАУ. Херсон : Айлант, 2007. Вип. 52. С. 76-82.

12. Шевченко Л.А., Чмель О.П., Хоменко С.В. Вплив мікродобрив та рістрегуляторів на продуктивність гібридів кукурудзи в умовах півночі України. Аграрні інновації. 2020. № 4. С. 73-78. https:// doi.org/10.32848/agrar.innov.2020.4.11.

13. Ушкаренко В. О., Нікішенко В. Л., Голобородько С. П., Коковіхін С. В. Дисперсійний і кореляційний аналіз у землеробстві та рослинництві : навчальний посібник. Херсон : Айлант, 2008. 272 с.

14. Лавриненко Ю. О., Коковіхін С. В., Найдьонов В. Г., Михайленко І. В. Наукові основи насінництва кукуру- дзи на зрошуваних землях півдня України. Херсон : Айлант, 2007. 256 с.

15. Marchenko T., Vozhegova R., Lavrynenko Y., Zabara P. Biometric indicators of lines - parental components of maize hybrids of different FAO groups depending on biopreparation procedure underconditions. Селекція і насінництво. 2021. № 119. С. 135-146. https://doi.org/10.30835/2413-7510.2021.237140.

16. Методика проведення ділянкового (POSTcontrol) i лабораторного сортового контролю / Держветфітослужба УІЕСР. Київ, 2012. 33 с.

17. Кириченко В.В., Петренкова В.П., Гур'єва І.А. [та ін.] Ідентифікація ознак кукурудзи (Zea mays L.) (навчальний посібник). Харків, IP ім. В.Я. Юр'єва УААН, 2007. $137 \mathrm{c.}$

18. Чучмий И. П., Моргун В. В. Генетические основы и методы селекции скороспелых гибридов кукурузы. Київ : Наукова думка, 1990. 284 с.

19. Домашнев П. П., Дзюбецкий Б. В., Костюченко В. И. Селекция кукурузы. Москва : Агропромиздат, 1992. 208 c.

20. Гаврилюк В. Н. Селекция и семеноводство раннеспелых и среднеранних гибридов кукурузы. Киев : Аграрна наука, 1998. 303 с.

21. Черчель В. Ю., Марочко В. А., Таганцова М. М. Обґрунтування індексу співвідношення висоти прикріплення верхнього качана до висоти рослини гібридів кукурудзи (Zea mays L.). Сортовивчення та охорона прав на сорти рослин. 2014. № 2. С. 40-44. https://doi.org/10.21498/2518-1017.2(23).2014.56127.

\section{REFERENCES}

1. Hadzalo, Ya.M., Vozhehova, R.A., Kokovikhin, S.V., Biliaieva, I.M., \& Drobit'ko, A.V. (2020). Naukove obgruntuvannya tekhnolohiy vyroshchuvannya kukurudzy na zroshuvanykh zemlyakh iz urakhuvannyam hidrotermichnykh chynnykiv i zmin klimatu [Scientific substantiation of technologies of corn cultivation on irrigated lands taking into account hydrothermal factors and climate change]. Zroshuvane zemlerobstvo - Irrigated agriculture, 73, 21-26. https://doi. org/10.32848/0135-2369.2020.73.3 [in Ukrainian].

2. Kokovikhin, S.V., Pysarenko, P.V., Bidnyna, I.O., Shariy, V.O., \& Boytsenyuk, Kh.I. (2020). Naukovopraktychni aspekty planuvannya ta operatyvnoho upravlinnya rezhymamy zroshennya sil's'kohospodars'kykh kul'tur iz vykorystannyam informatsiynykh tekhnolohiy [Scientific and practical aspects of planning and operational management of irrigation regimes of agricultural crops with the use of information technologies]. Zroshuvane zemlerobstvo - Irrigated agriculture, 73, 43-49. https://doi.org/10.32848/0135-2369.2020.73.8 [in Ukrainian].

3. Orlyanskiy, N.A., \& Zubko, D.G. (2005). Selektsiya kukuruzy na adaptivnost' i zagushcheniye posevov [Maize breeding for adaptability and thickening of crops]. Kukuruza i sorgo - Corn and sorghum, 5, 2-4 [in Ukrainian].

4. Zozulya, O.L., Palamarchuk, V.D., \& Mazur, V.A. (2009). Kukurudza stvorennya ta vyroshchuvannya hibrydiv [Corn creation and cultivation of hybrids]. Vinnytsya: FOP Danylyuk, 199 [in Ukrainian].

5. Palamarchuk, V.D., Palamarchuk, O.D., \& Kolisnyk, O.M. (2010). Selektsiya ta stvorennya hibrydiv kukurudzy, 
prydatnykh do mekhanizovanoho vyroshchuvannya ta vyrobnytstva al'ternatyvnykh dzherel enerhiyi [Selection and creation of maize hybrids suitable for mechanized cultivation and production of alternative energy sources]. Khraneniye i pererabotka zerna - Storage and processing of grain, 2(128), 23-25 [in Ukrainian].

6. Palamarchuk, V.D., Polishchuk, I.S., Kalen'ska, S.M., \& Yermakova, L.M. (2013). Biolohiya ta ekolohiya sil's'kohospodars'kykh Roslyn [Biology and ecology of agricultural plants]. Vinnytsya, 636 [in Ukrainian].

7. Kamenshchuk, B.D. (2009). Ahroekolohichnyy vplyv umov vyroshchuvannya na zernovu produktyvnist' hibrydiv kukurudzy riznykh hrup styhlosti [Agroecological influence of growing conditions on grain productivity of maize hybrids of different maturity groups]. Stan ta perspektyvy rozvytku roslynnyts'koyi haluzi v umovakh zmin klimatu: 4-a Mizhnar. nauk.-prakt. konf. molodykh vchenykh, 1-3 lypnya 2009. Kharkiv, 125-126 [in Ukrainian].

8. Sirokha, O.L. (2014). Vplyv udobrennya na biometrychni pokaznyky ta pokaznyky vyrivnyanosti roslyn kukurudzy riznoyi hrupy styhlosti [Influence of fertilizer on biometric indicators and indicators of leveling of corn plants of different maturity group]. Zbirnyk naukovykh prats' Vinnyts'koho natsional'noho ahrarnoho universytetu. Seriya: Sil's'kohospodars'ki nauky - Collection of scientific works of Vinnytsia National Agrarian University. Series: Agricultural Sciences, 5(82), 37-47 [in Ukrainian].

9. Marchenko, T.Yu. (2019). Innovative elements of cultivation technology of corn hybrids of different FAO groups in the conditions of irrigation. Natural sciences and modern technological solutions: knowledge integration in the XXI century: collective monograph. Lviv-Torun: Liha-Pres, P. 137-153. doi.org/ 10.36059/978-966-397-154-4/135-152 [in English].

10. Sikalova, O.V., Ivleva, T.V., Derkach, I.B., \& Chernobay, L.M. (2011). Novyy vykhidnyy material kukurudzy z kompleksom tsinnykh selektsiynykh oznak ta vlastyvostey [New source material of corn with a set of valuable selection traits and properties]. Henetychni resursy roslyn - Genetic resources of plants, 9, 131-137 [in Ukrainian].

11. Lavrynenko, Yu.O., Plotkin, S.Ya. et al. (2007). Adaptyvna kharakterystyka novykh hibrydiv kukurudzy [Adaptive characteristics of new maize hybrids]. Tavriys'kyy naukovyy visnyk - Taurian Scientific Bulletin, 52, 76-82 [in Ukrainian].

12. Shevchenko, L.A., Chmel', O.P., \& Khomenko S.V. (2020). Vplyv mikrodobryv ta ristrehulyatoriv na produktyvnist' hibrydiv kukurudzy $v$ umovakh pivnochi Ukrayiny [Influence of microfertilizers and growth regulators on productivity of maize hybrids in the conditions of the north of Ukraine]. Ahrarni innovatsiyi. Agricultural innovations, 4, 73-78. https://doi.org/10.32848/agrar. innov.2020.4.11 [in Ukrainian].

13. Ushkarenko, V.O., Nikishenko, V.L., Holoborod'ko, S.P., \& Kokovikhin, S.V. (2008). Dyspersiynyy i korelyatsiynyy analiz rezul'tativ pol'ovykh doslidiv [Dispersion and correlation analysis of results of field experiments]. Kherson : Aylant, 272 [in Ukrainian].

14. Lavrynenko, Yu.O., Kokovikhin, S.V., Nayd'onov, V.H., \& Mykhaylenko, I.V. (2007). Naukovi osnovy nasinnytstva kukurudzy na zroshuvanykh zemlyakh pivdnya
Ukrayiny [Scientific bases of corn seed production on irrigated lands of the south of Ukraine]. Kherson : Aylant, 256 [in Ukrainian].

15. Marchenko, T.Y., Vozhegova, R., Lavrynenko, Y., \& Zabara, P. (2021). Biometric Indicators of lines - parents of maize hybrids of different FAO groups depending on biological treatment on irrigation. Selektsiya $i$ nasinnytstvo - Breeding and seed production, 119. https:// doi.org/10.30835/2413-7510.2021.237140 [in English].

16. Metodyka provedennya dilyankovoho (POST-control) i laboratornoho sortovoho kontrolyu [Methods of conducting site (POST-control) and laboratory varietal control] (2012). Derzhvetfitosluzhba UIESR - State Veterinary Service UIESR. Kyiiv, 33 [in Ukrainian].

17. Kyrychenko, V.V., Petrenkova, V.P., Hur"yeva, I.A. et al. (2007). Identyfikatsiya oznak kukurudzy (Zea mays L.) [Identification of signs of corn (Zea mays L.)]. Kharkiv, 137 [in Ukrainian].

18. Chuchmiy, I.P., Morgun, V.V. (1990). Geneticheskiye osnovy i metody selektsii skorospelykh gibridov kukuruzy [Genetic bases and methods of selection of early ripening maize hybrids]. Kiyev : Naukova dumka, 284 [in Russian].

19. Domashnev, P.P., Dzyubetskiy, B.V., Kostyuchenko, V.I. (1992). Selektsiya kukuruzy [Maize breeding]. Moskva: Agropromizdat, 208 [in Russian].

20. Gavrilyuk, V.N. (1998). Selektsiya i semenovodstvo rannespelykh i srednerannikh gibridov kukuruzy [Selection and seed production of early-maturing and mid-early maize hybrids]. Kiyev: Agrarna nauka, 303 [in Russian].

21. Cherchel', V.Yu., Marochko, V.A., \& Tahantsova, M.M. (2014). Obgruntuvannya indeksu spivvidnoshennya vysoty prykriplennya verkhn'oho kachana do vysoty roslyny hibrydiv kukurudzy (Zea mays L.) [Substantiation of the index of the ratio of the height of attachment of the upper cob to the height of the plant of maize hybrids (Zea mays L.)]. Sortovyvchennya ta okhorona prav na sorty roslyn - Variety research and protection of plant variety rights, 2, 40-44. https:// doi.org/10.21498/2518-1017.2(23).2014.56127 [in Russian].

Вожегова Р. А., Лавриненко Ю.О., Марченко Т.Ю., Пілярська О.О., Забара П.П., Сахацький Г.І. Морфологічні показники гібридів кукурудзи різних груп ФАО залежно від елементів технології за умов зрошення

Мета дослідження - встановлення морфологічних показників та врожайності зерна інноваційних вітчизняних гібридів кукурудзи різних груп ФАО за різної густоти рослин та обробки біопрепаратами на краплинному зрошенні в умовах Південного Степу України. Ми визначали індекс співвідношення висоти прикріплення качана до висоти рослини гібридів кукурудзи залежно від густоти рослин і дії біологічних препаратів. Методи. Закладення польового досліду, вимірювально-розрахунковий (для вимірювання висоти рослини, висоти кріплення качана, обліку урожайності), математико-статистичний (для визначення листкового індексу, кореляційної залежності). Результати. Встановлено, що висота рослин істотно залежала від оброблення біопрепаратами гібридів кукурудзи. Максимальне значення висоти рослин було отримано за обробки біопрепаратами, зокрема в середньому за три роки висота рослин 
у разі оброблення Хелафріт комбі становила 265,6 см, за оброблення Біо-гелем - 264,1 см, приріст висоти до контрольного варіанту становив 2,9 см та 1,4 см відповідно. Загущеність посівів призводить до збільшення лінійної висоти рослини: максимальна висота рослин гібридів кукурудзи спостерігалася за густоти 90 тис. рослин/га. Оброблення біопрепаратами впливало на висоту прикріплення верхнього (продуктивного) качана на контрольному варіанті (111,4 см), причому Біо-гель збільшив висоту прикріплення качана на 0,8 cм (або на 0,7\%), а Хелафіт комбі - на 1,5 см (або на 1,3\%). Співвідношення висоти прикріплення качана до висоти рослини є генетично зумовленою ознакою, котра добре ідентифрікує зразки кукурудзи та може використовуватися для складання опису й характеристики нового матеріалу. Встановлено, що середньопізні гібриди негативно реагують на загущеність посівів, формуючи максимальну врожайність за густоти 70 тис. рослин/га (17,20-17,31 т/га) та різко знижують урожайність у разі загущеності посівів до 15,26-15,52 т/га. Середньостиглі гібриди максимум врожайності утворюють за густоти 80 тис. рослин/га - 12,47 т/га. Ранньостиглі гібриди максимальну врожайність продукують за густоти 90 тис. рослин/га - 11,36 т/га. Висновки. Ростові процеси рослин кукурудзи досить важливі з погляду на формування надземної маси та максимальну продуктивність. Архітектоніка рослин кукурудзи є факторіальною ознакою потенційної продуктивності, а також інформативною базою для визначення дії окремих елементів технології. Найефективнішим серед біопрепаратів виявився Хелафіт комбі: за його використання ранньостиглий гібрид Степовий показав найвищу врожайність зерна 11,53 т/га, приріст урожайності до контролю становив 1,04 т/га (або 9,9\%); середньостиглий гібрид Каховський показав урожайність на рівні 12,77 т/га, приріст урожайності - 1,14 т/га (або 9,8\%); урожайність середньостиглого гібрида Чонгар становила 16,71 т/га, приріст урожайності - 0,44 т/га (або 2,63\%); урожайність середньостиглого гібриду Арабат становила 16,91 т/га, приріст урожайності - 0,73 т/га (або 4,31\%).

Ключові слова: біометричні ознаки, висота рослини, висота першого продуктивного качана, індекс співвідношення, урожайність.

Vozhegova R.A., Lavrinenko Y.O., Marchenko T.Yu., Piliarska O.O., Zabara P.P., Sakhatsky G.I. Morphological parameters of maize hybrids of different FAO groups depending on the elements of technology under irrigation conditions

Purpose. Establishment of morphological indicators and grain yield of innovative domestic maize hybrids of different FAO groups, at different plant densities and treatment with biological products on drip irrigation in the conditions of the Southern Steppe of Ukraine. The index of the ratio of the height of attachment of the cob to the height of the plant of maize hybrids depending on the plant density and the action of biological preparations was determined. Methods. Establishment of field experiment, measuring and calculation - to measure the height of the plant, the height of the fork, yield accounting, mathematical and statistical - to determine the leaf index, correlations. Results. It was investigated that the height of plants significantly depended on the treatment of maize hybrids with biological products. The maximum value of plant height was obtained by treatment with biological products: for example, on average over three years, the height of plants by treatment Helafit combi was $265.6 \mathrm{~cm}$, by treatment Biogel $-264.1 \mathrm{~cm}$, the increase in height to the control variant was $2.9 \mathrm{~cm}$ and $1.4 \mathrm{~cm}$, respectively. Crop density leads to an increase in the linear height of the plant, the maximum plant height of maize hybrids was observed at a density of 90 thousand plants/ha. Treatment with biologicals affected the height of attachment of the upper (productive) cob: in the control version $-111.4 \mathrm{~cm}$, Bio-gel increased the height of attachment of the cob by $0.8 \mathrm{~cm}$ or $0.7 \%$, Helafit combi by $1.5 \mathrm{~cm}$ or $1,3 \%$. The ratio of the height of attachment of the cob to the height of the plant is a genetically determined trait that identifies well the samples of corn and can be used to compile a description and characteristics of the new material. It was found that mid-late hybrids react negatively to crop density. Mid-late hybrids form the maximum yield at a density of 70 thousand plants/ha - 17.20 $17.31 \mathrm{t} / \mathrm{ha}$ and sharply reduce the yield at crop density to 15.26-15.52 t/ha. Medium-ripe hybrids form the maximum yield at a density of 80 thousand plants/ha $-12.47 \mathrm{t} / \mathrm{ha}$. Early-maturing hybrids produce maximum yield at a density of 90 thousand plants/ha -11.36 t/ha. Conclusions. The growth processes of corn plants are very important in terms of the formation of aboveground mass and maximum productivity. The architecture of corn plants is a factorial sign of potential productivity, as well as an informative basis for determining the effect of individual elements of technology. The most effective among biological products proved to be the drug - Helafit combi: early-maturing hybrid Steppe showed the highest grain yield when using Helafit combi $11.53 \mathrm{t} / \mathrm{ha}$, yield increase to control $-1.04 \mathrm{t} / \mathrm{ha}$ or $9.9 \%$. The medium-ripe Kakhovsky hybrid showed a yield with the use of the drug Helafit combi - $12.77 \mathrm{t} / \mathrm{ha}$, an increase in yield of $1.14 \mathrm{t} /$ ha or $9.8 \%$. Medium-ripe hybrid Chongar showed a yield using the drug Helafit combi $16.71 \mathrm{t} / \mathrm{ha}$, a yield increase of $0.44 \mathrm{t} / \mathrm{ha}$ or $2.63 \%$. Medium-ripe hybrid Arabat showed a yield using the drug Helafit combi $16.91 \mathrm{t} / \mathrm{ha}$, yield increase $-0.73 \mathrm{t} / \mathrm{ha}$ or $4.31 \%$.

Key words: biometric traits, plant height, height of the first productive cob, ratio index, yield. 